\title{
HUBUNGAN KEAKTIFAN DALAM HIMA PRODI PPKN DENGAN INDEKS PRESTASI MAHASISWA PPKN UNIVERSITAS PGRI ADI BUANA SURABAYA
}

\author{
Suhartono \\ Prodi Pendidikan Pancasila dan Kewarganegaraan \\ Universitas PGRI Adi Buana Surabaya \\ suhartono@unipasby.ac.id
}

\begin{abstract}
This research was motivated by a student organization requires students to be active and independent role in running the holding organization. Students are expected to be able to contribute through his thinking in a student organization. The problem of this research is "How does the activity of the HIMA Education Program PPKn and there a relationship activeness of students in HIMA Education Program PPKn with achievement index of PPKn students on campus UNIPA Surabaya ". The goal is to determine the activity of the HIMA Education Program PPKn students and to determine the relationship of the activity of the HIMA Education Program PPKn student with student achievement index PPKn on campus UNIPA Surabaya. Activeness in this research is the students who are active as a board and as a member of HIMA PPKn UNIPA Surabaya. Achievement index in this research is the unit of ultimate value that describes the quality of teaching and learning process of each semester. In this study to measure the activity of students and grade is done by using questionnaires and documentation. Analyzed Data Technique using product moment correlation, the sample in this study consisted of 95 PPKn students UNIPA Surabaya year period 2015, 2016 , 2017. The data were obtained by questionnaire and documentation which there is a student IPK. Based on data analysis that has been done to produce a correlation coefficient -0,292 to 0,004 significant, because the significance $<0.05$ then Ho is rejected and Ha accepted. This means that there is a significant correlation between the activity of the HIMA Education Program PPKn with achievement index of PPKn students in UNIPA Surabaya.
\end{abstract}

Keywords: Motivation and Achievement Index

\section{PENDAHULUAN}

Organisasi merupakan wadah dalam sebuah kegiatan yang mempunyai sebuah tujuan, agar berjalan dengan baik maka organisasi juga harus dilaksanakan oleh SDM yang unggul. Adapun banyak pilihan organisasi yang bisa diikuti mahasiswa dalam suatu Universitas. Universitas selain tempat mahasiswa menimba ilmu juga tempat yang tepat bagi mahasiswa untuk aktif berkegiatan organisasi kemahasiswaan dalam upaya mengembangkan kemampuan sosialnya.

Karim (1985:318) memaparkan bahwa organisasi mahasiswa adalah proses dalam menyiapkan diri untuk 
memasuki organisasi yang lebih besar setelah keluar dari perguruan tinggi. Mahasiswa diharapkan mampu memberikan sumbangan melalui pemikirannya di suatu organisasi mahasiswa, sehingga masa kuliah dimanfaatkan dengan sebaik-baiknya.

Indeks Prestasi Mahasiswa (IPK) merupakan ukuran kemampuan mahasiswa sampai pada periode tertentu yang dihitung berdasarkan jumlah Satuan Kredit Semester (SKS) setiap mata kuliah yang telah ditempuh. Indeks Prestasi adalah nilai kredit ratarata yang merupakan satuan nilai akhir yang menggambarkan mutu penyelesaian satu program studi dari setiap mahasiswa tersebut.

Indeks Prestasi dihitung baik pada setiap akhir semester dengan hasil yang disebut IP semester maupun pada akhir program pendidikan lengkap satu jenjang dengan hasil yang disebut IP lengkap atau kumulatif (Putra, 2013). Kehadiran mahasiswa pada jam kuliah ada kaitannya dengan keaktifan mahasiswa dalam sebuah organisasi di kampus, seperti halnya mahasiswa yang lebih memilih aktif di suatu organisasi tersebut daripada hadir dikelas untuk mengikuti perkuliahan.

Berdasarkan paparan di atas, penelitian ini ingin menjawab permasalahan "Bagaimanakah keaktifan mahasiswa PPKn dalam HIMA Prodi
PPKn?" dan "Adakah hubungan keaktifan mahasiswa PPKn dalam HIMA Prodi PPKn dengan Indeks Prestasi mahasiswa PPKn di kampus UNIPA Surabaya?". Dengan demikian, penelitian ini bertujuan untuk mengetahui keaktifan mahasiswa PPKn dalam HIMA Prodi PPKn dan Untuk mengetahui hubungan keaktifan mahasiswa PPKn dalam HIMA Prodi PPKn dengan Indeks Prestasi mahasiswa PPKn di kampus UNIPA Surabaya.

\section{METODE PENELITIAN}

Pendekatan dalam penelitian ini adalah pendekatan kuantitatif dengan menggunakan metode survey untuk mencari adanya suatu hubungan antara variabel. Adapun bentuk paradigma penelitian ini adalah paradigma sederhana dengan satu variabel independen dan dependen (Sugiyono, 2013).

Teknik pengumpulan data yang digunakan kuesioner (angket) dan dokumentasi angket digunakan untuk mengetahui tingkat keaktifan mahasiswa dalam HIMA Prodi PPKn sedangkan dokumentasi untuk mendapatkan data IPK mahasiswa.

Pengambilan sampel penelitian menggunakan teknik Proportionate stratified random sampling digunakan dengan teknik solving untuk menentukan ukuran sampel. Sampel 
yang digunakan sejumlah 95 mahasiswa PPKn UNIPA Surabaya sedangkan populasi penelitian ini menggunakan populasi jenis finit karena jumlahnya ditentukan yaitu mahasiswa PPKn UNIPA Surabaya angakatan tahun 2015, 2016, 2017 yang terdiri dari 4 kelas dengan jumlah total 124 mahasiswa

Penelitian ini peneliti menggunakan dua macam teknik analisis data yaitu: a) statistik deskriptif dengan mencari mean, median, modus untuk menguji hipotesis deskriptif, dan b) Statistik inferensial jenis parametrik dengan teknik statistik korelasi product moment untuk menguji hipotesis asosiatif.

Sedangkan pengukuran data penelitian ini menggunakan skala pengukuran data interval dan ratio. Pengujian hipotesis menggunakan Rumus product moment sederhana. Korelasi produk moment sederhana digunakan untuk mengukur hubungan antar variabel sederhana, yaitu variabel independen dengan variabel dependen. Tetapi dalam penelitian ini statistik dihitung menggunakan aplikasi SPSS for windows versi 16.0 dengan teknik analisis korelasi produk moment setelah dilakukan uji normalitas.
Tabel 1.

Uji normalitas

\begin{tabular}{|c|c|c|c|}
\hline & & $\begin{array}{l}\text { Keakti } \\
\text { fan }\end{array}$ & Ipk \\
\hline $\mathrm{N}$ & & 95 & 95 \\
\hline \multirow{4}{*}{$\begin{array}{l}\text { Normal } \\
\text { Parameters }^{\text {a }}\end{array}$} & Mean & 55.04 & 52.0 \\
\hline & & & 9 \\
\hline & Std. & 5.200 & 5.01 \\
\hline & Deviation & $0 . \angle 00$ & 7 \\
\hline \multirow{3}{*}{$\begin{array}{l}\text { Most Extreme } \\
\text { Differences }\end{array}$} & Absolute & .099 & .114 \\
\hline & Positive & .079 & .059 \\
\hline & Negative & -.099 & -.114 \\
\hline \multicolumn{2}{|c|}{ Kolmogorov-Smirnov Z } & .968 & 1.10 \\
\hline \multicolumn{2}{|c|}{ Asymp. Sig. (2-tailed) } & .305 & .173 \\
\hline
\end{tabular}

a. Test distribution is Normal.

Hasil uji normalitas sebaran data keaktifan mahasiswa dalam HIMA Prodi PPKn UNIPA Surabaya berdistribusi normal, yaitu dengan nilai signifikasi 0,305>0,05. Data Indeks Prestasi mahasiswa PPKn UNIPA Surabaya berdistribusi normal, yaitu dengan nilai signifikasi 0,173>0,05. Korelasi produk momen digunakan untuk mencari ada/tidak adanya hubungan antar variabel. Setelah dilakukan analisis dengan program SPSS 16 untuk menguji hipotesis penelitian ini, maka diperoleh hasil koefisien korelasi adalah -0,292 dengan signifikan sebesar 0,004 karena signifikansi < 0.05 maka Ho ditolak dan Ha diterima.

\section{HASIL PENELITIAN}

Hasil penelitian ini dipaparkan dalam dua sajian. Sajian pertama disebut 
statistik deskriptif keaktifan mahasiswa dalam HIMA Prodi PPKn, dan sajian kedua uji hipotesis.

\section{Statistik deskriptif. Statistik} deskriptif variabel keaktifan mahasiswa dalam HIMA Prodi PPKn. Setelah dilakukan penelitian dengan pengambilan data melalui angket dapat diketahui bahwa keaktifan mahasiswa dalam HIMA Prodi PPKn masih tergolong baik.

Hal tersebut dibuktikan dengan hasil analisis angket dengan rata-rata 402 mahasiswa menjawab setuju dalam angket keaktifan mahasiswa dalam HIMA Prodi PPKn dengan persentase sebesar $85 \%$ dan dapat diperoleh mean/rata-rata keaktifan mahasiswa PPKn dalam HIMA Prodi PPKn 55,04. Standard Error adalah penyimpangan sampel sebesar 0,534.

Median/titik tengah dari angket keaktifan seluruh responden adalah 56,00 (untuk uji normalitas). Mode (modus) atau nilai yang sering muncul dari angket keaktifan seluruh responden adalah 52, Range adalah selisi (luas) data tertinggi (maksimum=65) dengan terendah (minimum=39), yaitu 26. Sum adalah jumlah total nilai 5229 dari 95 sampel. Untuk menguji hipotesis Hubungan keaktifan dalam HIMA Prodi PPKn dengan Indeks Prestasi mahasiswa PPKn UNIPA Surabaya didasarkan pada korelasi produk moment.
Tabel 2.

Data statistik korelasi produk momen

\begin{tabular}{llrr}
\hline \multicolumn{4}{c}{ Correlations } \\
\hline & \multicolumn{3}{c}{ KEAKTIF } \\
& AN & IPK \\
\hline KEAKTIF & $\begin{array}{l}\text { Pearson } \\
\text { AN }\end{array}$ & 1 & $-.292^{* *}$ \\
\cline { 2 - 4 } & $\begin{array}{l}\text { Correlation } \\
\text { Sig. (2- } \\
\text { tailed) }\end{array}$ & & .004 \\
\cline { 2 - 4 } & $\mathrm{N}$ & 95 & 95 \\
\hline IPK & $\begin{array}{l}\text { Pearson } \\
\text { Correlation }\end{array}$ & $-.292^{* *}$ & 1 \\
\cline { 2 - 4 } & $\begin{array}{l}\text { Sig. (2- } \\
\text { tailed) }\end{array}$ & .004 & \\
\cline { 2 - 4 } & $\mathrm{N}$ & 95 & 95 \\
\hline **. Correlation is significant at the 0.01 level \\
(2-tailed).
\end{tabular}

Jika nilai signifikan > 0,05 maka Ho di terima, artinya tidak adanya suatu hubungan. Tetapi jika nilai signifikan < 0,05 maka Ho di tolak, yang berarti $\mathrm{Ha}$ diterima / terdapat suatu hubungan. maka diperoleh hasil koefisien korelasi adalah -0,292 dengan signifikan sebesar 0,004 karena signifikansi $<0.05$ maka Ho ditolak dan $\mathrm{Ha}$ diterima artinya terdapat hubungan yang signifikan antara keaktifan dalam HIMA Prodi PPKn dengan Indeks Prestasi mahasiswa PPKn UNIPA Surabaya.

\section{PEMBAHASAN}

Penelitian Hubungan keaktifan dalam HIMA Prodi PPKn dengan Indeks Prestasi mahasiswa PPKn UNIPA Surabaya dengan menggunakan metode survey untuk mencari adanya suatu 
hubungan antara variabel. Adapun bentuk paradigma penelitian ini adalah paradigma sederhana dengan satu variabel independen dan dependen mengahasilkan temuan penelitian yaitu terdapat Hubungan keaktifan dalam HIMA Prodi PPKn dengan Indeks Prestasi mahasiswa PPKn UNIPA Surabaya.

Berdasarkan data hasil penelitian diketahui jumlah subjek sebagai sampel yang dianalisis yaitu 95 mahasiswa PPKn UNIPA Surabaya. Data variabel Keaktifan Mahasiswa dalam HIMA Prodi PPKn UNIPA Surabaya Setelah dilakukan penelitian dengan pengambilan data melalui angket dapat diketahui bahwa keaktifan mahasiswa dalam HIMA Prodi PPKn masih tergolong baik. Hal ini dibuktikan dengan hasil analisis angket dengan rata-rata 402 mahasiswa menjawab setuju dalam angket keaktifan mahasiswa dalam HIMA Prodi PPKn dengan persentase sebesar $85 \%$ dan data Indeks Prestasi dalam penelitian ini, maka dalam hal ini peneliti membahas Indeks Prestasi mahasiswa PPKn UNIPA Surabaya. Setelah dilakukan penelitian dengan pengambilan data melalui dokumentasi dapat diketahui bahwa diperoleh mean/rata-rata Indeks Prestasi mahasiswa PPKn 52.09. Data Indeks Prestasi mahasiswa PPKn UNIPA
Surabaya berdistribusi normal, yaitu dengan nilai signifikasi 0,173>0,05.

Setelah dilakukan pengujian hipotesis dengan korelasi produk momen ditemukan ada hubungan yang signifikan antara keaktifan dalam HIMA Prodi PPKn dengan Indeks Prestasi mahasiswa PPKn UNIPA Surabaya. Hasil penelitian ini didukung temuan penelitian Budianto dkk. (2014) dalam penelitiannya yang berjudul Pengaruh Aktivitas Mahasiswa Dalam Berorganisasi dan Disiplin Belajar Terhadap Prestasi Belajar (IP). Berdasarkan analisis data diperoleh: ada hubungan aktivitas mahasiswa dalam berorganisasi dengan prestasi belajar (indeks prestasi), ada hubungan disiplin belajar dengan prestasi belajar (indeks prestasi), ada hubungan aktivitas mahasiswa dalam berorganisasi dan disiplin belajar terhadap prestasi belajar (indeks prestasi).

\section{SIMPULAN}

Sesuai dengan hasil pengujian hipotesis maka dapat disimpulkan:

1. Keaktifan mahasiswa dalam HIMA Prodi PPKn UNIPA Surabaya dalam kategori baik.

2. Ada hubungan yang signifikan dengan tingkat hubungan sangat rendah antara keaktifan dalam HIMA Prodi PPKn dengan Indeks Prestasi mahasiswa PPKn UNIPA Surabaya. 


\section{SARAN}

1. Bagi pengurus HIMA Prodi PPKn UNIPA Surabaya.

Bentuklah Program Kerja (Proker) HIMA semenarik mungkin, keluarkan kreatifitas saudara dalam organisasi yang sangat bagus ini. Jangan menunggu orang lain untuk mengingatkan anda, kembangkan kreatifitas dan potensi yang saudara miliki. Pahami tugas dan tanggung jawab anda sebagai pengurus HIMA Prodi PPKn, sehingga seluruh kegiatan dapat dijalankan dengan baik.

2. Mahasiswa PPKn UNIPA Surabaya

Gunakan waktu perkuliahan semaksimal mungkin, kembangkan potensi saudara dengan aktif dalam kegiatan-kegiatan positif baik dilingkungan kampus maupun diluar kampus. Keaktifan saudara di suatu organisasi berpengaruh pada Indeks Prestasi saudara, sebagaimana jika saudara selalu aktif di organisasi dan meninggalkan tugas kuliah saudara maka IPK saudara dibawah rata-rata.

\section{DAFTAR PUSTAKA}

Arikunto, S. 2003. Manajemen Penelitian. Jakarta: Rineka Cipta.

Budianto, J., Rizal, Y., dan Nurdin, N. 2014. Pengaruh Aktivitas Mahasiswa Dalam Berorganisasi Dan Disiplin Belajar Terhadap Prestasi Belajar (IP). jurnal.fkip.(online), Vol 2, No 8http://jurnal.fkip.unila.ac.id/ind ex.p hp/JEE/article/view/6286 (Diakses tanggal 1 Februari 2018 23.30)

Darmadi, H. 2010. Pengantar Pendidikan Kewarganegaraan. Bandung: Alfabeta.

Karianto. 2014. kajian-pendidikanpancasila.

http://frintiskarianto.blogspot.co. id. Diakses tanggal 4 Februari 201821.30.

Karim, M. Rusli. 1985. Mahasiswa Cendekiawan Dan Masa Depan. Bandung: Alumni

Margono. 2010. Metodologi Penelitian Pendidikan. Jakarta: Rineka cipta

Organisasi mahasiswa di Indonesia. https://id.wikipedia.org/wiki/Or ganisasi mahasiswa_di_Indones ia, (Diakses tanggal 4 Februari 2018 22.30).

Putra, Pradana. 2013. Apa itu SKS. https://Pradanaputra8.blogsp ot.co.id/2013/03/apa-itu-sksapakah-indeks-prestasiIP.html (Diakses tanggal 5 Februari 2018 23.20).

Rivai, Veithzal. 2004. Kepemimpinan dan Perilaku Organisasi. Jakarta: Raja Grafindo Persada.

Salam, Burhanuddin. 2004. Cara Belajar yang Sukses di Perguruan Tinggi. Jakarta: Rineka Cipta 
Siregar, S. 2010. Statistika Deskriptif untuk Penelitian Dilengkapi Perhitungan Manual dan Aplikasi SPSS Versi 17. Jakarta: Rajawali Pers.

Soetopo, H. 2010. Perilaku Organisasi Teori dan Praktik dalam Bidang Pendidikan. Bandung: Remaja Rosdakarya.

Somantri. 2001. Menggagas Pembaharuan Pendidikan IPS. Bandung : PT Remaja Rosda karya

Sudarman. 2004. Belajar efektif di perguruan tinggi. Bandung: simbiosa rekatama media.

Sugiyono. 2013. Metode Penelitian Pendidikan Pendekatan Kuantitatif, Kualitatif dan RED. Bandung: Alfabeta.
Sugiyono. 2014. Statistika untuk Penelitian. Bandung: Alfabeta.

Sukardi. 2003. Metodologi Penelitian Pendidikan Kompetensi dan Praktiknya. Jakarta: PT. Raja Grafindo Persada.

Sutijono. 2012. Pedoman Akademik. Surabaya: Unipa

Sutrisno, E. 2011. Budaya Organisasi. Jakarta: Kencana Prenada Media Group.

Wikipedia. 2015. Organisasi Mahasiswa di Indonesia. http;//id.wikipedia.org/wiki/Org anisasi-mahasiswa-di-Indonesia. Diakses tanggal 1 Februari 2018 13.57. 